\title{
Clinical Guidelines (pedoman pelayanan klinis/medis)
}

\author{
Alan R. Tumbelaka
}

D alam sepuluh tahun terakhir, pedoman klinis telah menjadi sesuatu alat yang sangat erat dengan praktek klinis kedokteran. Hampir setiap hari, keputusan klinis di kamar praktek, standar operasi di rumah sakit dan klinik, serta kebijakan kesehatan pemerintah dan perusahaan asuransi mendapat pengaruh atau asupan dari pedoman klinis yang ada.

Clinical guidelines didefinisikan sebagai aturan yang dibuat secara sistematis untuk membantu para praktisi dalam penanganan pasien, untuk pelayanan kesehatan yang tepat dalam situasi yang spesifik. Pedoman ini dapat berisi tentang cara pemilihan prosedur diagnostik maupun skrining, cara memberikan pelayanan medis maupun bedah, seberapa lama pasien harus dirawat, dan rincian lainnya. ${ }^{1,2}$

Keuntungan utama dari suatu pedoman klinis adalah meningkatnya kualitas pelayanan yang diterima oleh pasien. Walaupun demikian, belum diperoleh bukti bahwa peningkatan tersebut terjadi dalam praktek seharihari dokter. Hal ini mungkin disebabkan oleh karena pengertian kualitas pelayanan yang berbeda antara dokter, pasien, pihak yang membayar (asuransi), dan mungkin juga karena bukti efektifitas pedoman klinis itu belum lengkap.

Sejak bertahun-tahun sebelumnya, para dokter telah menggunakan rekomendasi pengobatan, jadwal imunisasi, algoritma pengobatan, buku ajar dan jurnal, serta buletin dalam mengarahkan pelayanan kesehatan mereka. Perbedaan yang terjadi akhir-akhir ini adalah peningkatan upaya terfokus untuk secara sistimatik membuat ringkasan bukti-bukti penelitian untuk menyusun rekomendasi berbasis bukti. Pendekatan inimelibatkan banyak orang dengan latar belakang berbeda untuk secara sistimatis mengumpulkan serta membuat telaah kritis hasil-hasil penelitian untuk

\footnotetext{
Alamat Korespondensi:

Dr. Alan R. Tumbelaka, Sp.A(K).

Subbagian Infeksi \& Penyakit Tropis. Bagian IKA FKUI-RSCM.

Jl. Salemba no. 6, Jakarta 10430.

Telepon: 021-3914126. e-mail: alanrt@cbn.net.id.
}

kemudian menghasilkan pedoman klinis berbasis bukti (evidence-based guidelines).

Apakah yang disebut clinical practice guidelines (pedoman praktek klinis / pelayanan medis)? ${ }^{1,2}$ Clinical practice guidelines adalah,

- Suatu alat untuk memperkecil jarak antara pelayanan yang dilakukan sekarang dan pelayanan yang optimal.

- Suatu mekanisme untuk meningkatkan kualitas pelayanan kesehatan dan mengurangi biaya.

- Alat untuk menegaskan prosedur yang harus diikuti, sehingga memudahkan dokter dalam pengambilan keputusan.

- Suatu proses implementasi pelayanan yang berbasis bukti.

Sering terjadi kebingungan pemilihan istilah dalam implementasi pelayanan kesehatan, antara guideline, protokol, atau standar pelayanan medik maupun standar operasi pelayanan. Dalam petunjuknya, The New Zealand Guidelines Group (NZGG) memberikan beberapa tipe pedoman sebagai berikut: 3,4

- Best practice guideline / clinical guideline / practice guideline: "uraian yang disusun secara sistematis untuk membantu praktisi kesehatan dalam pelayanan kesehatan atau kelainan lain yang sesuai dalam situasi tertentu, dengan memperhatikan bukti untuk efektifitas dan juga merupakan dasar untuk perencanaan ...."

- Protocol : pedoman khusus yang harus diikuti secara rinci dan biasanya digunakan dalam situasi risiko tinggi, misalnya dalam resusitasi kedaruratan dan lainnya

- Consensus based guideline : biasanya pedoman ini dibuat sebagai kesepakatan dalam kelompok ahli

- Evidence based guideline : disusun setelah melakukan suatu pengumpulan dan penelaahan secara kritis terhadap informasi hasil penelitian. Biasanya disertakan juga catatan tentang strategi untuk menetapkan kekuatan bukti yang diperoleh, di samping adanya upaya memilah antara opini dan bukti. Juga selain mempersoalkan perbedaan hasil suatu eksperimen, biasanya diungkapkan perbedaan dalam kejadian yang menguntungkan dan merugikan. 
Sari Pediatri, Vol. 4, No. 4, Maret 2003

\section{Penyusunan pedoman pelayanan klinis (guideline)}

Penyusunan pedoman ini memakan waktu yang cukup lama serta biaya yang cukup besar. Beberapa langkah diperlukan untuk mendapatkan hasil yang optimal. Penetapan kelompok kerja yang menyusun pedoman ini juga akan sangat menentukan proses penyusunan ini. Latar belakang anggota kelompok akan sangat berpengaruh.

Tahapan penyusunan pedoman ini antara lain adalah sebagai berikut: ${ }^{1,2,4,5}$

1. Identifikasi topik, dapat berupa penyakit (misalnya: infeksi saluran kemih, penyakit jantung koroner), ataupun prosedur (histerektomi, resusitasi bayi baru lahir), dan lain-lain.

2. Penyempitan / penyederhanaan lingkup topik, antara lain untuk lebih mengarahkan tujuan penggunaan pedoman ini nantinya. Melalui tahap ini diharapkan kondisi medis yang akan ditata menjadi lebih jelas dan terarah.

3. Formulasi pertanyaan menyangkut diagnosis, terapi maupun pemeriksaan lainnya.

4. Penetapan sumber data yang akan dijadikan referensi.

5. Penelusuran literatur.

6. Telaah kritis dari informasi yang diperoleh.

7. Analisis semua bahan setelah selesai ditelaah, pembuatan neraca hasil penelitian serta mengelompokkan bobot hasil penelitian sesuai kesepakatan.

8. Penyusunan rekomendasi dan algoritma dengan gradasi yang sesuai dengan pelaksanaannya.

9. Diseminasi dan implementasi.

Langkah di atas dapat ditempuh dalam waktu yang berbeda-beda, tergantung besarnya topik dan bukti yang tersedia.

\section{Sistem gradasi hasil penelitian dan rekomendasi}

Suatu sistim untuk menentukan derajat kesahihan suatu hasil penelitian / artikel dan derajat rekomendasi untuk suatu pedoman pelayanan berbasis bukti telah berulang kali dibuat dan tergantung institusi yang menyusun pedoman tersebut. Berikut adalah contoh yang dibuat oleh Harbour dkk, dari Scottish Intercollegiate Guidelines Network Grading Review Group ${ }^{4,5}$, sebagai berikut.
Tabel 1. Derajat kesahihan bukti ( level of evidence ):

1++ Meta analisis kualitas tinggi, ulasan sistimatik Randomized Clinical Trial (RCT), atau RCT dengan risiko sangat rendah terjadi bias

1+ Meta analisis, ulasan sistimatik RCT, atau RCT dengan risiko rendah terjadi bias

1- Meta analisis, ulasan sistimatik RCT, atau RCT dengan risiko tinggi terjadi bias

$2++$ Ulasan sistimatik kualitas tinggi terhadap studi kasus control / kohort, atau studi kasus control / kohort kualitas tinggi dengan risiko perancu yang sangat rendah dan probabilitas kausal yang tinggi

2+ Studi kasus control / kohort, kualitas baik dengan risiko perancu yang rendah dan probabilitas kausal yang memadai

2- Studi kasus control / kohort, kualitas baik dengan risiko perancu yang tinggi dan probabilitas non kausal

3 Studi non analitik, misalnya laporan kasus atau kasus seri

$4 \quad$ Pendapat ahli

Tabel 2. Derajat rekomendasi (grade of recommendation )

A Sekurang-kurangnya 1 meta analisis, analisis sistimatik, atau RCT dengan derajat $1++$, atau analisis sistimatik RCT dengan derajat $1+$

B Adanya bukti dengan derajat 2++ atau ekstrapolasi dari studi dengan derajat $1+$ atau $1++$

C Adanya bukti dengan derajat 2+ atau ekstrapolasi dari studi dengan derajat $2++$

D Adanya bukti dengan derajat 3 atau 4 atau ekstrapolasi dari studi dengan derajat $2+$.

Penetapan derajat kesahihan bukti dan rekomendasi dapat saja dibuat lebih sederhana oleh institusi yang terkait dengan pedoman yang akan disusun, sepanjang dapat dipertanggungjawabkan.

\section{Kapan sebuah pedoman harus direvisi ?}

Perubahan pada bukti-bukti serta nilai yang ada di dalamnya, ketersediaan sumber daya kesehatan, perbaikan dalam sistim pelayanan kesehatan, merupakan alasan untuk melakukan perbaikan suatu pedoman pelayanan klinis. Hal ini biasanya terjadi setelah $3-5$ tahun. Untuk itu diperlukan suatu sistim / mekanisme untuk dapat melakukan identifikasi perubahan yang terjadi sehingga 
diperlukan perbaikan / revisi pedoman ${ }^{6}$.

Untuk menyusun pedoman dalam situasi atau lokasi tertentu, kita dapat melakukan proses penyusunan pedoman seperti dinyatakan di atas. Tetapi dapat pula dilakukan adopsi suatu pedoman yang yang sudah dibuat institusi lain dengan melakukan adaptasi. Dalam evidence-based medicine dikenal cara menilai suatu pedoman yang sudah ada dengan metode VIA (validity, importancy, applicability) yang tersedia dalam beberapa format. Salah satu format yang dibuat oleh Sackett dkk, terlampir dalam lampiran.

\section{Daftar pustaka}

1. Shekele PG, Woolf SH, Eccles M, Grimshaw JM. Developing guidelines. BMJ 1999; 318:593-6.

2. Feder G, Eccles M, Grol R, Griffiths $C$ and Grimshaw JM. Using clinical guidelines. BMJ 1999;318:728-30.

3. Woolf SH, Grol R, Hutchinson A, Eccles M, Grimshaw JM. Potential benefits, limitations, and harms of clinical guidelines. BMJ 1999; 318:527-30.

4. NZGG Guidelines Handbook. Dikutip dari http:// www.nzgg.org.nz/development/documents/nzgg_guideline_ handbook.pdf, tanggal 5 Mei 2003.

5. Harbour R, Miller J. A new system for grading recommendations in evidence based guidelines. BMJ 2001; 323:334-6.

6. Shekele PG, Eccles M, Grimshaw JM, Woolf SH. When should clinical guidelines be updated? BMJ 2001; 323:155-7.

\section{Lampiran}

\section{GUIDELINES WORKSHEET (Sackett D.L., Revised July 21, 1996)}

\section{Citation}

Are the recommendations in this guideline valid?

1. Were all important decision options and outcomes clearly specified?

2. Was the evidence relevant to each decision option identified, validated, and combined in a sensible and explicit way?

3. Are the relative preferences that key stakeholders attach to the outcomes of decisions (including benefits, risks and costs) identified and explicitly considered?

4. Is the guideline resistant to clinically sensible variations in practice?

Is this valid guideline or strategy potentially useful?

1. Does this guideline offer an opportunity for significant improvement in the quality of health care practice?

2. Is there a large variation in current practice?

3. Does the guideline contain new evidence (or old evidence not yet acted upon) that could have an important impact on management? Would the guideline affect the management of so many people, or concern individuals at such high risk, or involve such high costs that even small changes in practice could have major impacts on health outcomes or resources (including opportunity costs)?
Should this guideline or strategy be applied in yourpractice?

1. What barriers exist to its implementation? Can they be overcome?

2. Can you enlist the collaboration of key colleagues?

3. Can you meet the educational, administrative, and economic conditions that are likely to determine the success or failure of implementing the strategy?

a. credible synthesis of the evidence by a respected body

b. respected, influential local exemplars already implementing the strategy

c. consistent information from all relevant sources

d. opportunity for individual discussions about the strategy with an authority

e. user-friendly format for guidelines

f. implementable within target group of clinicians (without the need for extensive outside collaboration)

g. freedom from conflict with economic incentives, administrative incentives, patient expectations, and community expectations. 